\title{
Aksaray Üniversitesindeki Yabancı Uyruklu Öğrencilerin Gözünden Aksaray İlinin İmajı Üzerine Bir Araştırma
}

\author{
Zühal Fidan Baritci (Dr. Öğr. Üyesi) \\ Aksaray Üniversitesi İletişim Fakültesi \\ zuhal_fidan@hotmail.com \\ Fatih Baritci (Arş. Gör.) \\ Selçuk Üniversitesi İletişim Fakültesi \\ fatihbaritci@hotmail.com
}

Başvuru Tarihi: 01.05.2018

Yayına Kabul Tarihi: 04.07.2018

Yayınlanma Tarihi: 30.07.2018

Öz

Marka şehir, şehir pazarlaması gibi kavramsallaştırmalar yirminci yüzyılın son dönemlerinden itibaren birer fenomen haline gelmiştir. Bugün artık rekabet sadece şirketlerin ürettikleri ürünler ve markalar arasında değil, şehirler arasında da yaşanmaya başlamıştır. Bu süreç ise şehirlerinin birer marka olabilmesi adına altyapı çalıșmalarından kültürel faaliyetlere uzanan geniş bir portföyde girișimlerde bulunmasını gerektirmektedir. Bu çalışmada şehir markalama süreci ele alınmakta; özellikle de şehir imajının, marka olma sürecinde oynadığı kritik rolün üzerinde durulmaktadır. Bir şehir markası oluşturabilmek aynı zamanda şehrin tüm cazibesini gözler önüne sererek iyi bir imaja sahip olması için gerekli çabayı sergilemektedir. Dolayısıyla şehir markalama için şehrin nasıl bir imaja sahip olmak istediğinin cevabının verilmesi gerekmektedir. Bu çalışmada tarihi mirası, doğal güzellikleri ve coğrafi konumu bakımından çeşitli imkânlara sahip olan Aksaray'ın Aksaray Üniversitesi'nde okuyan yabancı uyruklu öğrencilerin gözünde sahip olduğu imaj ölçülmeye çalışılmıştır. Bu amaçla Aksaray Üniversitesi'ndeki 842 yabancı uyruklu öğrenciden 260’ının görüşlerini öğrenmek için anket uygulamasından yararlanılmıştır. Bu anketlerden 244 tanesi geçerli sayılmıştır. Çalıșmanın sonucunda Aksaray șehrine ve halkına yönelik imaj bileșenlerinin genel itibariyle olumsuz yönde olduğu, Aksaray’ın belirli bir imaja sahip olmadığı ve sahip olduğu önemli özellikleri hedef pazarına anlatmada eksikliklerinin olduğu sonucuna ulaşılmıştır.

Anahtar Kelimeler: Şehir Markalama, Şehir Pazarlama, Şehir İmajı, Aksaray. 
Research Article

\title{
A Research on City Image of Aksaray in the Eyes of Foreign Students at Aksaray University
}

\author{
Zühal Fidan Baritci (Asst. Prof. Dr.) \\ Aksaray University Faculty of Communication \\ zuhal_fidan@hotmail.com \\ Fatih Baritci (Res. Asst.) \\ Selçuk University Faculty of Communication \\ fatihbaritci@hotmail.com
}

Date Received: 01.05.2018

Date Accepted: 04.07.2018

Date Published: 30.07.2018

\begin{abstract}
Conceptualizations such as brand city, city marketing have become phenomena since the late twentieth century. Today, the competition is no longer just among products and brands that companies produce, but also among cities. This process requires that cities have initiatives in a broad portfolio extending from infrastructure work to cultural activities in order to be a brand. In this study, city branding process is considered especially the critical role of city image in the branding process. Creating a city brand is to make the effort to have a good image by showing all the charm of the city at the same time. Therefore, the question of what kind of image the city wants to have for city branding requires to be answered. In this study, it was tried to measure the image of Aksaray, which has historical heritage, natural beauties and various possibilities in terms of geographical location, from the eyes of foreign students studying at Aksaray University. For this purpose, survey method was applied to get the opinions of 244 foreign students of Aksaray University. In the result of study, it is understood that image components of both Aksaray and its people are negative; Aksaray has no specific image and city has lack of telling its properties to target market.
\end{abstract}

Keywords: City Branding, City Marketing, City Image, Aksaray. 


\section{Giriş}

Bugün artık birbirine benzer olan birçok șehir kendilerini diğerlerinden farklılaştırarak markalaşma çabalarına girişmektedirler (Altunbaş, 2007, 157). Bu noktada ortaya çıkan şehir markalama, hem akademisyenler hem de politikacılar için önemli bir çalışma konusudur. Ekonomik nedenlerin yanı sıra daha fazla turist çekmek ve yatırımcılar için şehrin cazip hale getirilmesi gibi nedenlerin şehir markalaşmasının amaçları arasında yer aldığını ifade etmektedirler (Işık ve Kösedağ, 2018, IX). Şehirler birçok konuda birbirleriyle yarışmanın yanı sıra küresel çapta turizmi, yatırımı ve yetenekleri kendilerine çekme noktasında da rekabet etmektedirler. $\mathrm{Bu}$ süreçte marka stratejisi giderek artan bir şekilde pazarlama dünyasından adapte edilerek; kentsel gelişim, yeniden yapılanma ve hayat kalitesi arayışıyla uygulanmaktadır (Dinnie, 2011, 3). Bunun yanı sıra bir şehrin markalaşma sürecinde şehrin görünüşünden sunulan hizmetin nitelik ve niceliğine, kent halkının sahip olduğu deneyim, inanç ve davranış kalıplarına kadar çeşitli faktörlerin devreye girdiği ifade edilmektedir (Işılk ve Erdem, 2016, 29). Şehirlerin markalaşma arzusu o kadar artmıştır ki, dünya basınında birçok şehrin kendisini cazip gösterebilmek için verdikleri mücadeleye şahit olunmaktadır. Hatta Financial Times gibi bir gazetenin reklamlarının \%5-\%10'nunu şehirlerin ve bölgelerin reklamları oluşturmaktadır (İlgüner ve Asplund, 2011, 44).

Özellikle politikacıların güçlü bir marka geliştirmek için yapması gerekenler arasında şehirle ilgili pozitif algıları ortaya çıkaracak marka özelliklerini dikkatlice belirlemek yer alır. Bu marka özellikleri, hedef gruplara "bu şehri düşündüğünde aklına ne geliyor?" sorusu sorulduğunda, şehrin onlarda uyandırması istenen özellikler olarak ifade edilebilir. Şehir markası özelliklerinin tanımlandığı ve üzerinde mutabık olunduğu süreç, tepeden inme bir şekilde değil, paydaşların uzlaşısı ile yürütülmelidir. Hayal gücü ve açık fikir ise şehrin benzersiz karakterini güçlü bir şekilde ifade eden uygun marka özelliklerinin belirlenmesi ve seçilmesi noktasında gereklidir. Hangi özellikler seçilirse seçilsin, bunların sadece geleneksel kanallarla değil aynı zamanda dijital medya aracılığıyla da etkili bir şekilde iletilmesi gereklidir (Dinnie, 2011, 5).

Bugün bazı durumlarda bir şehir imajı, ziyaretçiler, yatırımcılar ve şehrin sakinlerinin gözünde ilgili şehre yönelik fikirlerinin oluşmasında şehrin gerçekliğinden daha önemli bir rol oynadığını söylemek mümkündür. Bu nedenle pazarlama teknikleri, bir şehrin endüstri sonrası turizm, kültür ve gelişme merkezine dönüşmesine yardım etmesi için sıklıkla kullanılmaya başlanmıştır (Deffner ve Lioruris, 2005, 2). Bu durum șehirlerin imaj bileșenlerini mevcut ve potansiyel ziyaretçilere, yatırımcılara ve şehir sakinlerine en iyi şekilde göstermenin neden bu kadar önemli olduğunun göstergesi niteliğindedir. Şehir birçok açıdan kendisine diğer şehirlere kıyasla avantaj sağlayacak özelliklere sahip olabilir, ancak bunları hedef kitlesine anlatamadığı zaman bu avantajı kaybetmesi muhtemeldir. Bu sebeple şehirler kendilerini birer marka haline getirmede akıllı stratejiler geliştirerek kendi imajını tasarlayarak hedef kitlesinin zihninde cazip hale gelmelidir. Bu noktada şehrin yöneticileri ve diğer birimlerinin ortaklaşa yürüttüğü faaliyetler şehrin imajının gelişmesi için değerlidir. Işık $(2018,7)$ şehir imajı çalışmalarında sahip olunan değerlerin envanterlerinin yapılmasını ve hedef kitlelerin ilgi alanlarına yönelik olarak tanıtım stratejilerinin ve medya planlamasının yapılmasını önermektedir. 
Aksaray ili sahip olduğu doğal ve kültürel özelliklerin yanı sıra, coğrafi olarak Türkiye'nin merkezinde olmasının verdiği avantajla önemli bir kavşak durumundadır. Önemli markaların üretim merkezi olması, şehrin sanayi alanında da gelişmeler gösterdiğinin delili niteliğindedir. Bu çalışmada Aksaray Üniversitesi'nde okuyan yabancı uyruklu öğrencilerin gözünden Aksaray ilinin imajı ölçülmesi amacıyla anket yönteminden yararlanılmıştır. Yabancı öğrencilerin seçilmesindeki en temel amaç ise farklı ülkelerden gelen insanların gözünden Aksaray’ı görebilmek ve șehrin bir marka olabilmesi için gerekli olan yol haritasını çıkarmaya çalışmaktır.

\section{1. İmaj Oluşturmanın Marka Şehir Olma Açısından Önemi}

Şehir markasını gerekli kılan nedenler arasında uluslararası medyanın artan gücü, uluslararası seyahat ücretlerinin azalması, artan tüketici harcama gücü, sayıları sınırlı olan uluslararası yatırımcılar, yetenekli ve profesyonel göçmenler için rekabet halinde olma ve düşük maliyetli küresel medya tarafından teşvik edilen farklı kültürel yiyeceklere artan tüketici talepleri gibi etkenler gösterilebilir (Hanna ve Rowley, 2008, 63).

Marka olmayı amaçlayan şehirlerin sahip olduğu özellikler sayesinde kendisini cazip kılacağı bir pazar söz konusudur. Bu hedef pazarlar, şehre dair pazarlama mesajlarının aktarılacağı belirli bir hedef kitleyi tanımlamaktadır. İnsanlar şehirleri, algıları ve oluşturulan imajlar sayesinde tanımaktadır. $\mathrm{Bu}$ sebeple pazarlanması planlanan şehrin ilk yapması gereken hedef pazarlar tarafından dikkate değer bulunmasıdır. Bunun için de tanıtım faaliyetlerine önem verilmelidir (Ruhan, İnal ve Türkmen, 2011, 83).

Şehir markası oluşturma sürecinin nasıl yürütüleceğine dair cevaplanması gereken bazı sorular söz konusudur. Daha doğrusu hangi aşamaların nasıl yürütüleceğine dair kararların alınması gerekmektedir. $\mathrm{Bu}$ da bir markalama sürecine ve bunun sürdürülebilme çabalarına tekabül eder. Bu sebeple stratejik marka geliştirme ve stratejik marka yönetimi süreci marka değerinin yaratılması ve devam ettirilmesinde oldukça önemli bir süreçtir (Işık ve Ünlü, 2016, 242).

Işsk ve Erdem (2015, 29-35), marka şehir olma sürecinin 5 aşamada gerçekleşeceğini ifade etmektedirler:

- Stratejik marka analizi safhası: Bu aşamada stratejik yönetim anlayışıyla hareket edilir ve SWOT analizi ile şehrin durumu tespit edilir.

- Marka kimliği oluşturma safhası: Bu aşamada şehre bir kişilik ve kimlik kazandırılır; şehrin insanların zihninde nasıl yer etmesi isteniyorsa ona göre bir strateji oluşturulur.

- Marka değeri oluşturma safhası: Hem duygusal hem de fiziksel bir farkındalık oluşturarak şehre bir üstünlük kazandırmaya çalışılır. Şehri diğerlerinden farklılaştıracak özellikler bulunur ve uygun bir şekilde sunulur.

- Konumlandırma safhası: Bu aşamada şehrin insanların zihninde marka olarak yer etmesine çalışılır. Diğer şehirlerden farkları, üstünlükleri ve bunun yanı sıra sahip olduğu avantajlar vurgulanır.

- Uygulama safhası: Öncelikle halkla ilișkiler faaliyetleri ile șehre karșı duygusal bir bağ kurularak güven tesis edilmeye çalıșlır. Ardından bașta reklam olmak üzere diğer tanıtım faaliyetlerinden yararlanılarak halkla ilişkiler uygulamaları desteklenir. 
Şehir markası stratejisi geliştirmek için anahtar soruların cevaplarını arayan bir başka araştırmacı olan Insch $(2011,13-14)$, bu süreçte özellikle şehir sakinlerinin bu konuda ne kadar önemli bir rol oynadığının üzerinde durmaktadır. Cünkü bu kişiler şehrin yerel kültürünü şekillendirir; oradaki işletmelerin sahibi olarak onları yönetir ve şehrin kişiliğini temsil ederler. Insch'e göre bir şehrin marka olma sürecinde geçmesi gereken aşamalar şu şekildedir:

Tablo 1: Bir Şehir Markası Geliştirmek için Anahtar Sorular

\begin{tabular}{|c|c|c|}
\hline Kimlik & $\begin{array}{l}\text { Biz kimiz? } \\
\text { Neyi temsil ediyoruz? }\end{array}$ & $\begin{array}{l}\text { Toplum, ortak varlıklarına, kişiliğine, çekici } \\
\text { özelliklerine ve benzer şeylere kıymet verir. Şehrin } \\
\text { yer (place) kimliğinin yönlerini seçici olarak } \\
\text { vurgularlar. Bu aşamada ortam, toplumu marka } \\
\text { stratejine sahip çıkmaya teşvik etmelidir. }\end{array}$ \\
\hline $\begin{array}{l}\text { Beklenen } \\
\text { Sonuçlar }\end{array}$ & $\begin{array}{l}\text { Neyi başarmak istiyoruz? } \\
\text { Kimi cezbetmek istiyoruz? } \\
\text { İlerlemeyi nasıl ölçeceğiz? }\end{array}$ & $\begin{array}{l}\text { Kentin gelişim hedefleriyle marka özünün entegrasyonu } \\
\text { ve tutarlıığı söz konusu olmalıdır. Şehrin cezbetmek } \\
\text { istediği unsurlar ile bu sürecin nasıl ölçüleceğinin } \\
\text { belirlenmesi gerekir. Bu göstergelerin seçiminde } \\
\text { şehir sakinlerinin katılımı çok önemlidir. }\end{array}$ \\
\hline İletişim & $\begin{array}{l}\text { Yaratıcı ve ikna edici bir şekilde } \\
\text { hedef kitlemize nasıl erişip } \\
\text { onlarla etkileşime geçeceğiz? } \\
\text { Güvenilir bir şekilde şehrimizin } \\
\text { hikâyesini nasıl anlatacağız? }\end{array}$ & $\begin{array}{l}\text { Bu aşamada seçilen hedef kitlenin şehir ve } \\
\text { şehrin sunduklarıyla ilgili diyaloğa katıımının nasıl } \\
\text { sağlanacağına ve bu kişilere nasıl erişileceğine } \\
\text { odaklanılmalıdır. Geleneksel medya kanallarının } \\
\text { dışında, şehir markası inşa etmek için sosyal } \\
\text { medyanın da kullanııması önemlidir. }\end{array}$ \\
\hline Uyumluluk & $\begin{array}{l}\text { İletişimde tutarlılığı ve } \\
\text { istikrarı sağlamak için } \\
\text { programları ve çalışmaları } \\
\text { nasıl organize edeceğiz? }\end{array}$ & $\begin{array}{l}\text { Uygulamanın en önemli kısmı belirli girişimlerin } \\
\text { kimin tarafında yapılacağıdır. Burada büyük resim } \\
\text { göz önünde bulundurulmalı ve faaliyetlerin ne } \\
\text { kadar tutarlı olduğuna da dikkat edilmelidir. }\end{array}$ \\
\hline
\end{tabular}

$\mathrm{Bu}$ çalışma kapsamında şehir markalama/pazarlama sürecinde önemli bir rolü olan "şehir imajı" kavramı üzerinde durulmaktadır. Rizzi ve Dioli'ye $(2010,303)$ göre şehir markalama süreci güçlü bir imaj inşası stratejisini gerektirir. Dolayısıyla bir şehir markası oluşturabilmek aynı zamanda şehrin tüm cazibesini gözler önüne sererek iyi bir imaja sahip olması için gerekli çabayı sergilemektir.

Şehir markalama için şehrin nasıl bir imaja sahip olmak istediğinin cevabının verilmesi gerekmektedir. Şehrin imajı iki aşamalı bir süreç neticesinde oluşturulur. İlk aşama, şehre dair bir farkındalık ve beklenti oluşturulmasıdır. Bu noktada ana ve alt imaj temaları belirlenir. Ana imaj temaları sanayi, ticaret, eğitim, turizm vb. olabilirken; alt imaj temaları bina stilleri, anıtlar, tarihi miraslar, çevre vb. olabilir. İkinci aşamada ise oluşturulması hedeflenen farkındalık ve beklentiyi destekleyecek iletişim faaliyetlerinde bulunulur. Başta halkla ilişkiler olmak üzere reklam ve çeșitli pazarlama tekniklerinden yararlanılabilir (Işık ve Erdem,2015, 22-23).

Markalaşma bir iletişim şeklidir ve iletişim her zaman iki yönlü bir süreçtir. Tüketici tarafında, marka kavramının merkezinde kalite ve değer algılarının yanı sıra marka çağrışımlarını ve duygularını içeren marka imajı yer almaktadır. Özet olarak marka kimliği, marka konumlandırma ve marka imajının ilişkisi aşağıdaki gibidir (Kavaratzis ve Ashworth, 2005, 508): 


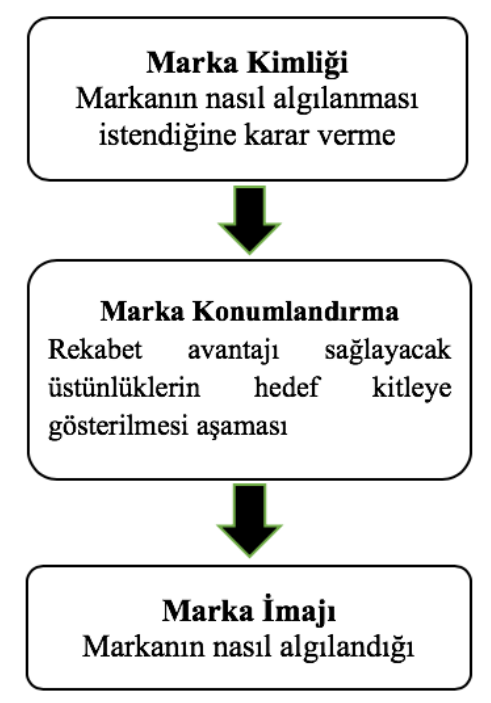

Şekil 1: Şehir Markası Oluşturma Süreci

Şekil 1'den hareketle Altunbaş (2007, 161) "bir şehrin markalaşma sürecine girebilmesi için pazarlama stratejisi aşamalarının marka kimliği, konumlandırma ve imaj yönetimi aşamalarına bilinçli destek vermesi" gerektiğini vurgulamaktadır.

Gilboa ve diğerleri (2015, 51-52) turistleri ve şehir sakinlerini çekmek için şehir markalamanın ilk adımı şehir imajının belirlenmesi olduğunu ifade etmekte ve "bu zihinsel fotoğrafların bileșenleri nedir?" sorusuna cevap aramaktadır. Bu soruya cevap vermek için de 2001 ve 2013 yıları arasında şehir markalaması ile ilgili yayınlanmış akademik çalışmaları incelemişlerdir. Bu çalışmalarda imaj unsurlarını göstermede öne çıkan tanımlayıcılar ise tarih ve (tarihi) miras, kültür, ekonomi, eğlence ve gece hayatı, altyapı, alışveriş merkezleri, çevre, dinlenme faaliyetleri, barınacak yer, güvenlik, spor tesisleri, parklar, hizmetler, otoyola erişim, sağlık tesisleri, lokantalar ve yeşil alanlardır.

Bir şehrin imajı, insanların o şehirle ilgili sahip oldukları kanı, fikir ve izlenimlerin toplamıdır. Başka bir ifadeyle imaj, o yer hakkındaki onlarca bilgi ve çağrışımın sade bir hali gibidir. İnsanların zihninde o yere ait var olan onlarca bilgi arasından bazılarının öne çıkmasıdır. İmaj sadece basit bir kanı değil, o kanıların tamamıdır. İnsanların zihninde aynı yere yönelik imajlar farklı farklı olabilir. Bu sebeple bir şehir için çekici bir imaj oluşturmak istendiğinde, hedef kitlenin bu imajın ne olduğunu keşfetmesi sağlanmalıdır. Burada unutulmaması gereken şey, imajın bir şehir için hedef kitlelerin gözünde ana etken olduğu gerçeğidir (İlgüner ve Asplund, 2011, 265).

Başarılı bir marka șehir olabilmek için diğer şehirlerden farklılaşma ve öne çıkma noktasında avantaj sağlayacak olan tarihi, kültürel, doğal vs. her türlü zenginliğin hedef kitlelere gösterilmesi beklenmektedir. Doğal olarak bir şehir bütün bu unsurları bir arada bulunduramayabilir. Bu noktada ise sahip olduğu zenginliği ön plana çıkararak o yönde bir marka kimliği oluşturmayı, buna göre kendisini konumlandırmayı ve hedef kitlenin/pazarın gözünde olumlu bir imaja sahip olmayı amaçlaması en uygun yöntem olarak kabul edilebilir.

\section{Yöntem}

$\mathrm{Bu}$ çalışmada sosyal bilimlerde sıklıkla kullanılan veri toplama tekniklerinden birisi olan anket tekniği kullanılmıştır. Bu çalışmada tarihi mirası, doğal güzellikleri 
ve coğrafi konumu bakımından çeşitli imkânlara sahip olan Aksaray'ın Aksaray Üniversitesi'nde okuyan yabancı uyruklu öğrencilerin gözünde sahip olduğu imaj ölçülmeye çalışılmıştır. 2017-2018 eğitim-öğretim döneminde Aksaray Üniversitesi bünyesinde 842 yabancı uyruklu öğrenci tespit edilmiştir. Bu amaçla 23 Mart-20 Nisan 2018 tarihleri arasında yabancı uyruklu öğrencilerin gözünden Aksaray şehir imajının belirlenmesine yönelik olarak 260 yabancı uyruklu öğrenciye yüz yüze anket uygulanmıştır. Araştırmada amaçlı rastlantısal örneklem yöntemi kullanılmıştır. Anket sorularının oluşturulmasında Işık ve Erdem (2015), Işık ve Erdem (2016), Özdemir ve Karaca (2009) çalışmalarından yararlanılmıştır. Çalışmada demografik özellikler, Aksaray' dair bilgilerin öğrenilmesine yönelik açık uçlu soruların yanı sıra yabancı öğrencilerin Aksaray'a dair düşüncelerini ölçmeye yönelik yargılar için alınan cevaplarda 5'li Likert Ölçeği kullanılmıștır. Bu sebeple oluşturulan yargılar 1 kesinlikle katılmıyorum", 2 "katılmıyorum", 3 "kararsızım", 4 "katılıyorum" ve 5 "kesinlikle katılıyorum” şeklinde oluşturulmuştur.

\section{Bulgular}

Araştırmada elde edilen veriler SPSS 23 programına aktarılarak analiz edilmiștir. 260 yabancı öğrenciye anket yapılmış olup bunların 244'ü geçerli sayılmıştır. Ankete katılanların \% 75,9'u erkek \% 23,7'si kadın ve \% 89,8'i 18-25 yaș, \% 10,2'si 26-35 yaș aralığındadır. Araştırmaya katılanların aylık gelirleri incelendiğinde ise \% 10,2'si 250 TL ve altı, \% 23,8'i 251-500 TL, \% 23,0'ü501-750 TL, \% 25,8'i 7511000 TL ve \% 17,2'si 1001 TL ve üzeri gelire sahip olduğu verileri elde edilmiștir. Katılımcıların ülkeleri ise şöyledir: \% 38,9'u Türkmenistan, \% 37,7'si Azerbaycan, \% 9,0'u Suriye, \% 3,3'ü Yemen, \% 2,5'i Afganistan, \% 1,6'sı Irak, \% 1,2'si Pakistan, \% 1,2'si ise Somali'dir. Ayrıca daha az katılımcı sayısının olduğu ülkeler ise şu şekilde sıralanmaktadır: Nepal, Hollanda, İran, Tacikistan, Mali, Fas, Myanmar, Kırgızistan.

Katılımcıların ne kadar süredir Aksaray'da yaşadıkları soruduğunda \% 28,3'ü 1 yıl, $\%$ 25,0'i 1-2 yıl, \% 40,2'si 3-4 yıl, \% 6,5'sı ise 5 yıl ve üzeri yanıtını vermiştir. Ankete katılan yabancı öğrencilerin Aksaray'ı daha önceden bilip bilmediklerine dair yöneltilen soruya \% 80,3'ü hayır yanıtını verirken, \% 19,7'si evet yanıtını vermiştir. \% 0,8'i ise soruyu yanıtsız bırakmıştır. Bu soruya evet yanıtını verenlerin \% 9,0'u tanıdıkları aracılığıyla, \% 5,3'ü internetten, \% 3,3'ü ziyaret esnasında, \% 1,6'sı şehir tanıtım günlerinde, \% 0,4'ü üniversite tercihi yaparken Aksaray hakkında bilgi sahibi olduklarını belirtmişlerdir.

Tablo 2: Aksaray Kelimesinin Yaptığı Çağrışım

\begin{tabular}{|l|c|c|}
\hline & Sayı & \% \\
\hline Olumlu & 171 & 70,1 \\
\hline Olumsuz & 73 & 29,9 \\
\hline Toplam & 244 & 100,0 \\
\hline
\end{tabular}

Katılımcıların zihnindeki Aksaray algısının değerlendirilmesi amacıyla "Aksaray kelimesinin yaptığı çağrışım" sorulmuştur. Ankete katılan yabancı öğrencilerin \% 70,1'i Aksaray kelimesinin kendilerinde olumlu, \% 29,9’u olumsuz çağrışım yaptığını ifade etmiştir. Yukarıdaki tablodan da anlaşılacağı üzere araştırmaya katılanların çoğunluğunun zihninde Aksaray ile ilgili çağrışımların olumlu olduğu sonucuna ulaşılmıştır.

Araştırmada katılımcılara yöneltilen sorulardan biri de "Aksaray kelimesini duyduğunuzda aklınıza gelen ilk şey nedir?" şeklindedir. Açık uçlu olarak yöneltilen 
bu soruya verilen cevaplar oldukça çeşitlidir. \% 18,4'ü üniversite, \% 13,1'i İstanbul Aksaray, \% 10,7'si şehir, \% 8,6'sı Malaklı köpeği, \% 8,6'sı Hasandağı yanıtını vermiştir. Bu yanıtların yanı sıra Ebulfeyz Elçibey Caddesi, kuraklık, kabalık, şehir, Somuncu Baba, kültürel bir şehir, gelişmekte olan bir yer, kafeler caddesi, evliyalar diyarı, Salihler şehri, türbe, kötü bir yer, Ihlara, taş, abart egzozlu arabalar, dindar söylemler, tarihi ve turistik yerler, beyaz şehir, huzur, Ulu Camii, saat kulesi, mutluluk, Eğri Minare, güzel bir şehir, saray, Kılıçaslan, Tuz Gölü, köy, Kapadokya, ağaç, geri kalmış şehir, Ali Baba Tekkesi, 68 plaka, 15 Temmuz Meydanı, güvenli bir şehir, Recep Tayyip Erdoğan, Selçuklu șehri gibi yanıtlar da verilmiştir. Bu yanıtlar da akıllara Aksaray ile ilgili tarihi ve doğal güzelliklerin, șehre ait dini ve tarihi figürlerin, simge ve sembollerin yeterince ön plana çlkarılmadığının göstergesi olduğu şeklinde değerlendirilebilir.

Tablo 3: Aksaray'a IIlk Geldiğinizde En Çok Dikkatinizi Çeken Şey

\begin{tabular}{|l|c|c|}
\hline & Sayı & \% \\
\hline Şehir halkı & 67 & 27,5 \\
\hline Tarihi ve turistik yerleri & 59 & 24,2 \\
\hline Doğal güzellikleri & 44 & 18,0 \\
\hline Alışveriş merkezleri & 32 & 13,1 \\
\hline Sanayisi & 18 & 7,4 \\
\hline Kuraklık & 6 & 2,5 \\
\hline Huzur ve sakinlik & 6 & 2,5 \\
\hline Küçük şehir & 3 & 1,2 \\
\hline Kötü esnaf & 3 & 1,2 \\
\hline Düzenli olması & 2 & 0,8 \\
\hline Suyunun kötü olması & 2 & 0,8 \\
\hline Üniversite & 2 & 0,8 \\
\hline Toplam & 244 & 100,0 \\
\hline
\end{tabular}

"Aksaray'a ilk geldiğinizde en çok dikkatinizi çeken şey nedir" sorusunu araştırmaya katılanların \% 27,5'i şehir halk1, \% 24,2'si tarihi ve turistik yerleri, \% 18,0'i doğal güzellikleri, \% 13,1'i alışveriş merkezleri yanıtını vermiştir. Buna göre yabancı öğrencilerin şehirle ilgili en çok dikkatlerini çeken şeyin şehir halkı olduğu sonucuna ulaşılmıştır. Şehir markalama sürecinde şehir sakinlerinin sahip oldukları bazı özelliklerin son derece önemli olduğu bilinmektedir. Çünkü yerel kültürün oluşturucusu, yerel işletmelerin yöneticileri ve şehrin değerlerini bilenler o şehrin sakinleridir. Onların oluşturacağı olumlu ya da olumsuz imaj, şehre yönelik algıların şekillenmesinde kritik bir rol oynayacaktır.

Tablo 4: Aksaray'a Dair Șu An Sahip Olunan İzlenim

\begin{tabular}{|l|c|c|}
\hline & Sayı & \% \\
\hline Çok Kötü & 20 & 8,2 \\
\hline Kötü & 27 & 11,1 \\
\hline Ne İyi Ne Kötü & 95 & 38,9 \\
\hline İyi & 87 & 35,7 \\
\hline Çok İyi & 15 & 6,1 \\
\hline Toplam & 244 & 100,0 \\
\hline
\end{tabular}

Aksaray'a dair katılımcıların şu anda sahip olduğu izlenimi öğrenmek amacıyla yöneltilen soruya katılımcıların \% 38,9'u ne iyi ne kötü yanıtını verirken; \% 41,8'i iyi bir izlenime, \% 19’3 ü ise kötü bir izlenime sahip olduğu yanıtını vermiştir. 
Tablo 5: Aksaray'da Yaşamayı Başkasına Tavsiye Eder Misiniz?

\begin{tabular}{|l|c|c|}
\hline & Sayı & \% \\
\hline Evet & 125 & 51,2 \\
\hline Hayır & 119 & 48,8 \\
\hline Toplam & 244 & 100,0 \\
\hline
\end{tabular}

"Aksaray'da Yaşamayı Başkasına Tavsiye Eder Misiniz?" sorusuna katılımcıların \% 51,2'si evet yanıtını verirken, \% 48,8'i hayır yanıtını vermiştir. Evet ve hayır yanıtlarının arasındaki farkın birbirine çok yakın olması Aksaray için olumsuz bir durumdur. Çünkü Aksaray'da yaşama tecrübesine sahip olan neredeyse her 2 kişiden 1'inin șehri başkalarına tavsiye etmemesi șehir adına kötü bir durumun göstergesidir.

Aksaray ilinin soyut imaj unsurlarına yönelik katılımcılara yöneltilen sorulara alınan yanıtların yüzdesi Tablo 6'deki gibidir:

Tablo 6: Katılımcıların Aksaray'a Dair Düşünceleri

\begin{tabular}{|c|c|c|c|c|c|c|}
\hline & 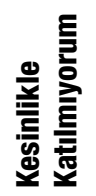 & 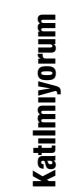 & 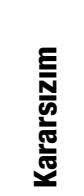 & 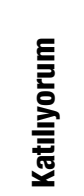 & 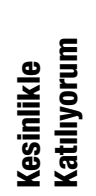 & AO \\
\hline Aksaray ucuz bir şehirdir. & 12,3 & 13,1 & 13,1 & 38,1 & 23,0 & 3,46 \\
\hline Aksaray huzurlu ve sakin bir şehirdir. & 13,5 & 12,7 & 13,9 & 37,3 & 22,5 & 3,42 \\
\hline Aksaray sanayi şehridir. & 16,8 & 25,4 & 18,9 & 28,7 & 10,2 & 2,90 \\
\hline Aksaray temiz bir şehirdir. & 14,8 & 27,0 & 23,4 & 26,2 & 8,6 & 2,86 \\
\hline Aksaray'da barınma sorunu yoktur. & 16,8 & 22,5 & 29,9 & 22,1 & 8,6 & 2,83 \\
\hline Aksaray sağlık hizmetleri bakımından kalitelidir. & 16,8 & 25,4 & 28,7 & 22,1 & 7,0 & 2,77 \\
\hline Aksaray doğal güzellikleriyle zengin bir şehirdir. & 20,5 & 26,2 & 21,3 & 20,1 & 11,9 & 2,76 \\
\hline $\begin{array}{l}\text { Aksaray'da sanatsal ve kültürel } \\
\text { etkinlikler yeterlidir. }\end{array}$ & 17,6 & 32,4 & 23,8 & 20,9 & 5,3 & 2,63 \\
\hline Aksaray ulaşım hizmetleri kaliteli bir şehirdir. & 24,6 & 26,6 & 21,7 & 19,3 & 7,8 & 2,59 \\
\hline Aksaray gelişmiş bir şehirdir. & 22,5 & 37,5 & 21,7 & 13,5 & 4,5 & 2,39 \\
\hline
\end{tabular}

Katılımcıların gözünden Aksaray imajının ortaya konulmaya çalıșıldığı bu bölümde Aksaray'a dair yargılar verilmiş olup Likert ölçeğiyle değerlendirme yapmaları istenmiştir. Buna göre "Aksaray ucuz bir şehirdir" yargısına yönelik katılımcılardan alınan yanıtlara göre katılımcıların \% 25,4'ü bu yargıya katılmazken; katılımcıların \% 60,6'sı Aksaray'ın ucuz bir şehir olduğu yönünde görüş bildirmiştir. \% 13,1'lik bir kesim ise bu yargı karşısında kararsız kalmıştır.

Katılımcıların Aksaray’ı huzurlu ve sakin bir şehir olarak görüp görmediklerini tespit etmek amacıyla "Aksaray huzurlu ve sakin bir şehirdir"yargısına ne oranda katıldıklarını ifade etmeleri istenmiştir. Araștırmaya katılanların \% 26,2'si Aksaray'ı huzurlu ve sakin bir şehir olarak görmezken; \% 59,8'i ise Aksaray'ın huzurlu ve sakin bir şehir olduğunu belirtmiştir. \% 13,9’luk bir grup ise kararsız olduğunu beyan etmiştir.

Katılımcılardan "Aksaray sanayi şehridir" yargısına katılıp katılmadıklarını ifade etmeleri istenmiștir. Araştırmaya katılanların \% 42,2'si Aksaray’ın bir sanayi şehri olmadığını ifade etmişlerdir. Aksaray'ın sanayi șehri olduğunu söyleyenler ise \% 38,9'da kalmıştır. \% 18,9'luk bir kesim ise fikir beyan etmemiștir.

Katılımcılardan "Aksaray temiz bir șehirdir" yargısına katılıp katılmadıkları sorulmuştur. Aksaray'ın temiz bir şehir olmadığını söyleyenlerin oranı \% 41,8 iken; 
bu yargıya katılanların oranı \% 34,8 olarak tespit edilmiştir. \% 23,4'lük bir grup ise fikri olmadığını belirtmiştir.

Katılımcılardan Aksaray'da barınma sorunu olup olmadığına dair fikirlerini öğrenmek amacıyla oluşturulan "Aksaray'da barınma sorunu yoktur" yargısına verdikleri yanıtlar değerlendirilmiştir. Buna göre katılımcıların \% 39,3'ü bu yargıya katılmazken; \% 30,7'lik bir kesim Aksaray'da barınma sorunu olmadığını ifade etmiştir. Katılımcılardan \% 29,9’u de bu yargı karşısında kararsız olduklarını belirtmiştir.

Aksaray'daki sağlık hizmetlerinin kalitesinin değerlendirilmesi amacıyla oluşturulan "Aksaray sağlık hizmetleri bakımından kalitelidir" yargısına katılımcıların \% 42,2'si katılmazken; katılımcıların \% 29,1'i Aksaray'daki sağlık hizmetlerini kaliteli bulmaktadır. Bu yargıya \% 28,7'lik bir grup ise "kararsızım" seçeneğini işaretlemiştir.

"Aksaray doğal güzellikleri bakımından zengin bir şehirdir" yargısına katılımcıların verdiği yanıtlar şu şekildedir. Bu yargıya katılmayanların oranı \% 46,7 iken; katılanların oranı ise \% 32'dir. Katılımcıların \% 21,3'ü ise bu yargıyla ilgili fikri olmadığını ifade etmiştir.

"Aksaray'da sanatsal ve kültürel etkinlikler yeterlidir" yargısına katılımcıların \% 49,6'sı katılmadığını ifade etmiştir. Katılımcıların \% 26,2'si ise Aksaray ile ilgili bu yargıya katıldıklarını söylemişlerdir. \% 23,8'i ise fikir beyan etmemiştir.

"Aksaray ulaşım hizmetleri kaliteli bir şehirdir" yargısına katılımcıların verdiği yanıtlar şu şekildedir: Katılımcıların \% 50,8'i bu yargıya katılmazken; katılımcıların \% 27,1'i Aksaray'ın ulaşım hizmetleri bakımından kaliteli bir şehir olduğu yönünde fikir beyan etmişlerdir. \% 21,7'lik bir kesim ise bu yargı karşısında kararsız olduklarını ifade etmişlerdir.

Katılımcılara "Aksaray gelişmiş bir şehirdir" yargısına ne oranda katıldıkları sorulmuştur. Araştırmaya katılanların \% 60,0’ı bu yargıya katılmadıklarını ifade ederken; \% 18,0'i ise Aksaray'ın gelişmiş bir șehir olduğu yanıtını vermiştir. \% 21,7'lik bir kesim ise bu fikri olmadığını ifade etmiştir.

Katılımcıların Aksaray'a dair düşünceleri arasında ucuz bir şehir olduğu yargısına (A0: 3,46$)$ en yüksek oranda önem verirken, bunu huzurlu ve sakin bir şehir olma yargısı (AO: 3,42) takip etmektedir. Katılımcıların Aksaray'ın gelişmiş bir şehir olduğu yargısına (A0: 2,39) gösterdikleri önem düzeyi ise oldukça düşüktür. 
Tablo 7: Katılımcıların Aksaray Halkına Dair Düşünceleri

\begin{tabular}{|c|c|c|c|c|c|c|}
\hline & 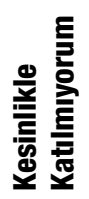 & 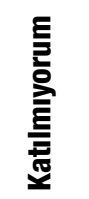 & 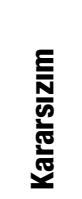 & 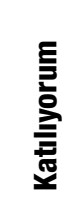 & 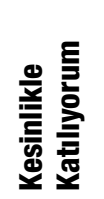 & AO \\
\hline Aksaray halkı dindardır & 10,2 & 10,7 & 23,8 & 35,7 & 19,7 & 3,43 \\
\hline Aksaray halkı yardımseverdir. & 18,4 & 18,4 & 21,7 & 28,7 & 12,7 & 2,98 \\
\hline Aksaray halkı samimidir. & 13,5 & 24,2 & 25,4 & 26,6 & 10,2 & 2,95 \\
\hline Aksaray halkı hoşgörülüdür. & 13,9 & 25,0 & 25,4 & 26,2 & 9,4 & 2,92 \\
\hline Aksaray halkı cömerttir. & 14,8 & 23,4 & 29,1 & 22,5 & 10,2 & 2,90 \\
\hline Aksaray halkı açık fikirlidir. & 15,6 & 22,5 & 30,3 & 22,5 & 9,0 & 2,86 \\
\hline Aksaray halkı kibardır. & 17,6 & 26,2 & 26,6 & 21,3 & 8,2 & 2,76 \\
\hline
\end{tabular}

Katılımcıların Aksaray halkına dair düşüncelerini öğrenmek amacıyla olușturulan yedi farklı yargıya katılıp katılmadıkları öğrenilmeye çalışılmıştır. Bu yargılara yönelik katılımcıların görüşleri Tablo 8' de detaylı bir şekilde gösterilmiştir. Buna göre Aksaray halkına dair yapılan değerlendirmelerden Aksaray halkının dindar olduğu yönündeki yargıya katılımcıların \% 54,5’i katıldıklarını beyan etmişlerdir. "Aksaray halkı yardımseverdir" yargısına katılımcıların çoğunluğu olan \% 41,4'lük bir kısmı katılmaktadır. "Aksaray halkı samimidir" yargısına ise katılımcıların çoğunluğu olan \% 37,7’lik bir kısım katılmamaktadır. Ayrıca "Aksaray halkı hoşgörülüdür" yargısına katılmayanların \% 38,1 iken; Aksaray halkının cömert olduğuna dair geliştirilen yargıya katılmayanların \% 37,3'tür. Katılımcıların \% 138,1'i Aksaray halkını açı fikirli bulmamaktadır. Son olarak katılımcıların \% 41,8'i Aksaray halkının kibar olmadığı yönünde fikir beyan etmiştir. Katılımcıların Aksaray halkına dair en çok önem verdiği $(A 0: 3,43)$ "Aksaray halkı dindardır" yargısı olurken; "Aksaray halkı kibardır" yargısı ise katılımcıların en az önem verdiği yargı durumundadır. 
Tablo 8: Aksaray'da Yaşama Süresi ile Aksaray’ı Başkalarına Tavsiye Etme Çapraz Tablosu

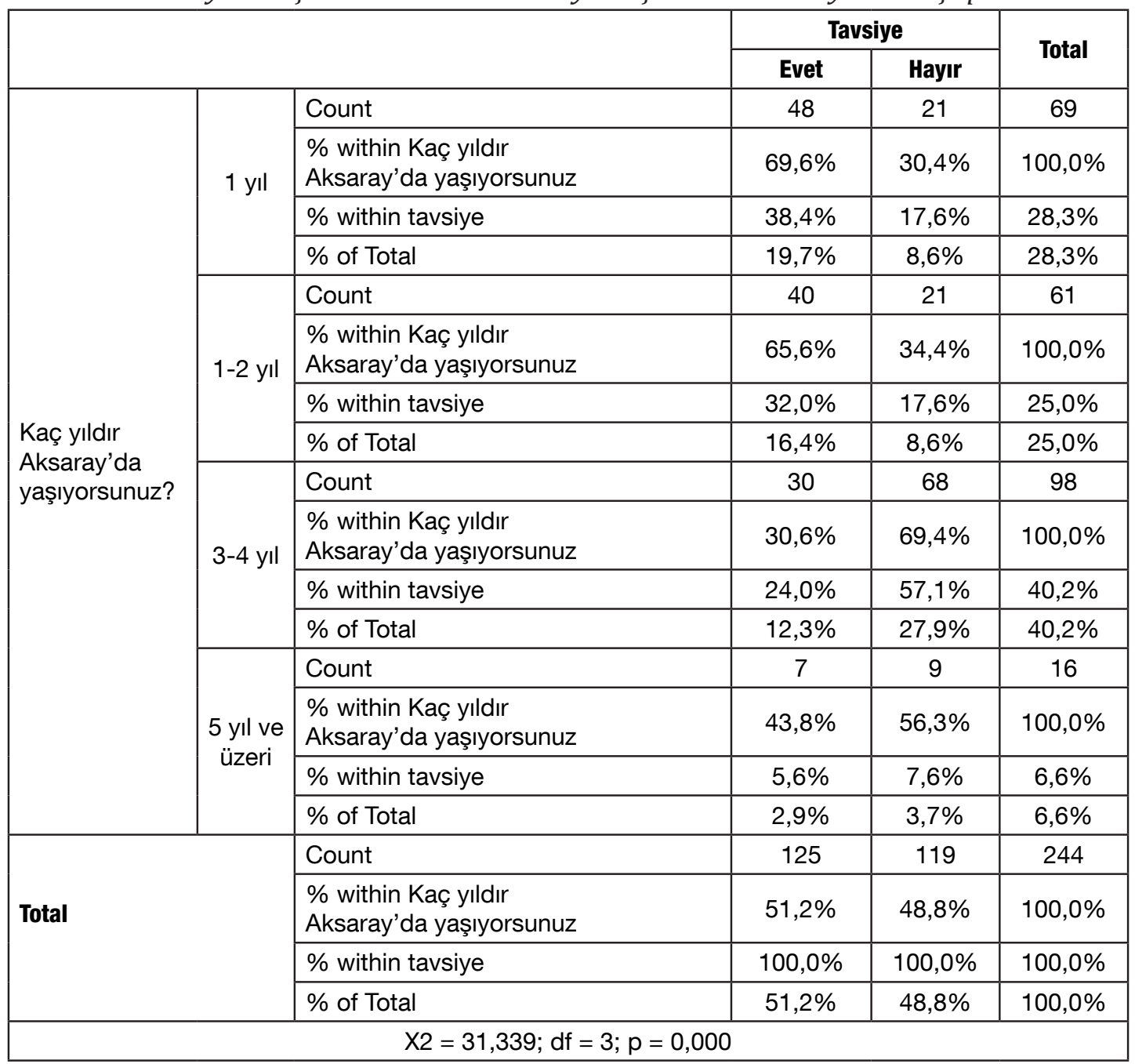

Tablo 8'deki veriler incelendiğinde Aksaray'da yaşayanların yıllara göre dağılımı şu şekildedir: 1 yıldır yaşayanlar \%28,3, 1-2 yıl aralığında yaşayanlar \%25,0, 3-4 yıl aralığında yaşayanlar \%40,2, 5 yıl ve üzeri yaşayanlar \%6,6. Tabloda yer alan ve ki kare analizi sonucunu gösteren $p$ değerinden elde edilen veriye göre $(p<0,05)$ Aksaray'da yaşama süresi ile şehri başkalarına tavsiye edilmesi arasında anlamlı bir ilişki bulunmaktadır. Aksaray'da 1 yıldır yaşayanların Aksaray'da yaşamayı başkalarına tavsiye etme oranları \%69,6; Aksaray'da 1-2 yıldır yaşayanların bu oranı ise \%65,6'dır. Aksaray'da 3-4 yıldır yaşayanların Aksaray şehrini başkalarına tavsiye etme oranı bakıldığında ise \%69,4'ünün Aksaray'ı tavsiye etmediği; 5 yıl ve üzeri yaşayanların \%56,3'ünün Aksaray’ı başkalarına tavsiye etmediği verilerine ulaşılmıştır. Buradan hareketle Aksaray Üniversitesi'nde okuyan yabancı öğrencilerin şehirde yaşama süreleri ile Aksaray'ı başkalarına tavsiye etme ilişkilerini gösteren çapraz tablodan yola çlkarak, Aksaray'da yaşama süresi arttıkça şehrin başkalarına tavsiye edilme yüzdesinin azaldığı gözlemlenmektedir. Aksaray'a yeni gelenlerin ilk olarak olumlu bir izlenime kapılıyor olması ve başkalarına Aksaray'da yaşamayı tavsiye ediyor olması olumlu bir durumken; Aksaray'da yaşama süresinin artmasıyla birlikte şehrin başkalarına tavsiye edilme yüzdesinin düşmesi olumsuz bir durumun göstergesidir. 


\section{Sonuç}

Şehirler yirminci yüzyılın son dönemi itibariyle markalaşma konusunda ciddi adımlar atmaya başlamış ve bu amaçla pazarlama yöntemlerini uygulamaya başlamışlardır. Bugün artık şehirler tıpkı ürün/hizmet gibi marka haline getirilmeye çalışılmaktadır. Aksaray da yerel yönetimleri temelinde marka şehir olma arzusunu dile getiren ve bu amaçla faaliyetler düzenleyen bir şehirdir. Bu çalışmada elde edilen veriler, Aksaray'ın markalaşma sürecine katkı sağlaması ve hedef kitle nezdinde sahip olduğu mevcut imajın belirlenmesinde önemli bir rol oynayacaktır. Bu sayede Aksaray'ın yerel yönetimleri markalaşma noktasında yol haritasını güncelleme imkânı kazanabilecektir.

Çalışma kapsamında Aksaray şehrinin ve halkının imaj bileşenleri ölçülmeye çalıșılmıştır. Katılımcıların Aksaray şehrine dair verdikleri yanıtlardan hareketle șehrin "ucuz", "sakin ve huzurlu" olma noktasında olumlu bir imaja sahip olduğu; "sanayi”, "temizlik", "barınma", "sağlık hizmetleri", "doğal güzellikler", "sanatsal ve kültürel etkinlikler", "ulaşım hizmetleri” ve gelişmişlik" noktasında olumsuz bir imaja sahip olduğu tespit edilmiștir. Katılımcıların Aksaray halkına dair verdikleri yanıtlardan hareketle Aksaraylıların "dindarlık" ve "yardımseverlik" noktasında olumlu bir imaja sahip olduğu; "samimilik", "hoşgörülülük”, “cömertlik”, "açık fikirlilik" ve "kibarlık" noktasında olumsuz bir imaja sahip olduğu anlaşılmıștır. Ayrıca yine çalışmada elde edilen verilerden biri de Aksaray'da yaşama süresi arttıkça Aksaray'da yaşamayı başkalarına tavsiye edenlerin yüzdesinin azalmasıdır.

Çalışmada tespit edilen olumsuz imajların olumlu hale getirilmesi Aksaray şehrinin marka olması için önemlidir. Yatırımcılar açısından cazip bir yer olma açısından Aksaray'ın sahip olduğu sanayi potansiyelinin hedef pazara iyi anlatılması; turistler açısından cazip bir yer olma açısından sahip olunan doğal güzelliklerin tanıtımının yapılması ve şehre dair olumsuz olarak görülen noktaların geliştirilmesi son derece önemlidir.

Çalışmada Aksaray halkının sahip olduğu olumsuz imajların düzeltilmesi için ise Aksaraylıların şehirdeki öğrencilerle ve şehre gelen diğer yabancılarla kurulan iletişimi geliştirmeleri önemli bir adım olacaktır. Şehir halkının markalaşma için oynadığı kritik rol yukarıda detaylı bir şekilde ele alınmıştır. Katılımcıların ilgili sorulara verdiği yanıtlarda da yer alan "kötü esnaf", "kabalık" gibi Aksaray halkına yönelik olumsuz imajın değișmesi durumunda șehre yönelik yaklaşımları da olumlu etkileyecektir. Şehir sakinleri, şehrin kimliğini oluşturan en önemli bileşenlerden biridir. Şehrin kültürünü oluşturan, aktaran ve en iyi bilenler olarak şehir sakinleri şehir markalaşması sürecinde son derece önemli bir göreve sahiptir.

Şehrin sahip olduğu olumsuz imaj bileșenlerinin olumluya dönüștürülmesi noktasında hem Aksaray'ın yerel yönetimlerine ve sivil toplum kuruluşlarına hem de şehrin halkına önemli görevler düşmektedir. İlk olarak Aksaray kelimesi duyulduğunda insanların aklına gelmesi istenen şeyin belirlenip bu yönde stratejik iletişim çalışmaları yapılması önemli bir başlangıç olabilir. Başta şehrin sahip olduğu doğal güzelliklerden dini kimliklere, tarihi zenginliklerden mimariye kadar birçok unsur bu bağlamda tercih edilebilir. Ihlara Vadisi, Malaklı Köpeği ya da Somuncu Baba bu noktada örnek olarak değerlendirilebilecek önemli zenginliklerdir. Bununla beraber şehrin imaj bileşenleri Aksaray'ın yerel yönetimleri ve sivil toplum kuruluşlarının mutabakatıyla belirlenmelidir. Böylece hem şehrin imaj bileşenleri 
hem de şehrin özdeşleştirilmek istendiği figür belirlenmiş olup, markalaşma süreci daha stratejik ve kontrol edilebilir hale gelebilir.

Aksaray markalaşma gibi bir amaca sahip olsa da bu noktada stratejik bir planlamanın olup olmadığı tartışma konusudur. Çalışmada Aksaray deyince akla gelen ilk şeyin ne olduğu sorulduğunda alınan yanıtların belirli bir ağırlık taşımaması, hatta İstanbul Aksaray yanıtının fazla olması Aksaray belirli bir imaja sahip olmadığını göstermektedir. Aksaray'ın sahip olduğu ve onu diğer şehirlerden farklılaştıran özelliklerin belirlenip, şehrin bu doğrultuda konumlandırılması gerekmektedir. Daha sonra da üst ve alt imaj öğeleri belirlenmeli ve şehrin tanıtımı halkla ilişkiler faaliyetleri öncelikli olarak yapılmalıdır.

\section{Kaynakça}

Altunbaş, H. (2007). Pazarlama İletișimi ve Şehir Pazarlaması "Şehirlerin Markalaşması”, Selçuk Üniversitesi İletişim Fakültesi Akademik Dergisi, 4(4), 156-162.

Dinnie, K. (2011). Introduction to the Theory of City Branding. K.Dinnie (Ed.) City Branding: Theory and Cases (s. 3-7). Hampshire: Palgrave Macmillan.

Gilboa, S., Jaffe, E. D., Vianelli, D., Pastore, A. ve Herstein, R. (2015). A Summated Rating Scale for Measuring City Image. Cities, 44, 50-59

Hanna, S. ve Rowley, J. (2008). An Analysis of Terminology Use in Place Branding, Place Branding and Public Diplomacy, 4(1), 61-75.

Insch, A. (2011). Branding the City as an Attractive Place to Live. K. Dinnie (Ed.) City Branding: Theory and Cases (s. 8-14). Hampshire: Palgrave Macmillan.

Işık, M ve Erdem, A. (2015). Nasıl Marka Şehir Olunur?. Konya: Eğitim Yayınevi.

Işık, M. ve Erdem, A. (2016). Şehirler ve İmajlar: Marka Şehir Olma Sürecinde Sakarya İmajı Üzerine Bir Çalışma. Akademia 4(3), 28-34.

Işık, M. ve Ünlü, S. (2016). İnovasyon Çağında Yeni Marka Anlayışı: Marka İnovasyonu. A. Z. Özgür ve A. İşman (Ed.) İletişim Çalışmaları 2016, (s. 237-250) Sakarya: Sakarya Üniversitesi.

Işık, M. ve Kösedağ, M. S. (2018). Marka Şehir Düzce Türkiye'de Düzce Algısı- İmajı Üzerine Bir Araştırma. Konya: Eğitim Yayınevi.

Işık, M. (2018). Marka Şehir Sakarya Türkiye'de Düzce Algısı \& İmajı Üzerine Bir Araștırma. Konya: Eğitim Yayınevi.

İlgüner, M. ve Asplund, C. (2011). Marka Şehir. İstanbul: Markating Yayınları.

İri, R., İnal, M. E. ve Türkmen, H. H. (2011). Șehir Pazarlamasında Bilinirliğin Önemi: Niğde Yöresinin Bilinirliğinin Ölçülmesine Yönelik Bir Araştırma. Niğde Üniversitesi İ̈BF Dergisi, 4(1), 81-96.

Liouris, C. ve Deffner, A. (2005). City Marketing-A Significant Planning Tool for Urban Development in A Globalised Economy, 45th Congress of the European Regional Science Association: "Land Use and Water Management in a Sustainable Network Society": 23-27 August 2005-Amsterdam: (p. 1-21). 
Özdemir Ş. ve Karaca Y. (2009). Kent Markası ve Marka İmajının Ölçümü: Afyonkarahisar Kenti İmajı Üzerine Bir Araştırma. Afyon Kocatepe Üniversitesi Íktisadi ve İdari Bilimler Fakültesi Dergisi, 11(2), 195-213.

Rizzi, Paolo ve Diolo, Ilaria (2010). Strategic Planning, Place Marketing and City Branding: The Italian Case. Journal of Townand City Management, 1(3), 300317. 
